\title{
Effect of Main Engine Placement and Propeller Shaft Inclination on Ship Performance
}

\author{
Agoes Santoso ${ }^{1}$, Irfan Syarief Arief ${ }^{2}$, Ngizuddin Masro'i ${ }^{3}$, Semin $^{4}$ \\ (Received: 30 January 2020 / Revised: 16 March 2021 / Accepted: 17 March 2021)
}

\begin{abstract}
- placement of the ship propulsion system components might also affect the value of the ship's resistance and thrust. Included in the placement of the ship's propulsion system components are the placement of the main engine and propeller shaft inclination. Changes in the placement of the main engine will affect the location of the center of gravity of the ship which affects the trim and the amount of resistance of the ship. While propeller shaft inclination will affect the direction of thrust produced by the propeller. In this research, an analysis of how big the effect of the placement of the main engine and the propeller shaft inclination on various angles for the $60 \mathrm{GT}$ fishing vessel on the ship's performance by using simulation. Simulations were performed with Numeca Fine Marine software using the Actuator Disk Propeller method. Propeller shaft inclination variations are $1^{0}, 2^{\circ}, 3^{\circ}$, and $4^{\circ}$. At each propeller shaft inclination, there are two variations of the placement of the main engine at a distance of $4 \mathrm{~m}-6.5 \mathrm{~m}$ from the AP and $5.5 \mathrm{~m}-8 \mathrm{~m}$ from the AP. Based on the results of the simulation that has been done, the greater the angle of the propeller shaft inclination, the more resistance value will be even smaller, and the thrust produced is also smaller. When the main engine is shifted towards FP, the resistance value will be greater, and the thrust generated is also greater. The most optimal conditions are on the rake of the propeller shaft $4^{0}$ and the main engine position $4 \mathrm{~m}-6.5 \mathrm{~m}$ from the $\mathrm{AP}$, the total resistance value of the ship $=9648.97 \mathrm{~N}$ and the thrust $=16520.66$, torque $=1867.46, \mathrm{KT}=\mathbf{0 . 1 5 6 9}, \mathrm{KQ}=\mathbf{0 . 0 1 7 7}, \mathrm{J}=\mathbf{0 . 2 8 2 7}$ and propulsion efficiency $=0.3991$. This configuration was chosen because to make the ship move at the same speed, the configuration requires less power.
\end{abstract}

Keywords — main engine placement, propeller shaft inclination, resistance, thrust.

\section{INTRODUCTION}

$\mathrm{W}$ hen operating at sea, a ship must have the ability to maintain official speed (Vs) as planned. This means that the ship must have a propulsion system design that can overcome the overall drag forces that occur in order to meet the service speed standards. The basis for designing the main drive system is the coordination between prime movers and the transmission and propulsor system. These three main components constitute a unity which in the planning process cannot be reviewed separately. Errors in the design will bring enormous consequences to the following conditions: not achieving the speed of the planned ship service, inefficient fuel oil consumption, the decline in an economic value of the operation of the ship, and the influence on the level of vibration that occurs in the hull [1].

The transmission system is a subsystem of the propulsion system. Components of this system consist of shaft, gearbox, and bearing. This system has two functions, forwarding power from prime movers to propulsor and continuing the thrust from propulsor to the hull of the ship [2] [3].

Agoes Santoso, is with Department of Marine Engineering, Institut Teknologi Sepuluh Nopember, Surabaya, 60111, Indonesia. E-mail: agoes@its.ac.id

Irfan Syarief Arief is with Department of Marine Engineering, Institut Teknologi Sepuluh Nopember, Surabaya, 60111, Indonesia. Email: irfansya@its.ac.id

Ngizuddin Masro'i is with Department of Marine Engineering, Institut Teknologi Sepuluh Nopember, Surabaya, 60111, Indonesia. Email: ngizuddin15@mhs.its.ac.id

Semin is with Department of Marine Engineering, Institut Teknologi Sepuluh Nopember, Surabaya, 60111, Indonesia. E-mail: semin@its.ac.id
Generally, the phase of the ship resistance and propulsion calculation only takes into account the design of the hull without taking into account the placement of the ship propulsion system components. Even though the placement of the ship propulsion system components might also affect the value of the ship's resistance and thrust. Included in the placement of the ship's propulsion system components are the placement of the main engine and propeller shaft inclination. Changes in the placement of the main engine will affect the location of the center of gravity of the ship which affects the trim and the amount of resistance of the ship. While the slope of the propeller shaft will affect the direction of thrust produced by the propeller. The direction of the thrust will be parallel to the propeller shaft so that it will have two force components namely the horizontal force that will move the ship and the vertical force that gives a lift to certain parts of the ship. The lift will affect the trim of the ship which will have an impact on the resistance that occurs on the ship.

\section{A. Center of Gravity}

The center of gravity of an object is a point where all the mass of the object is assumed to be concentrated at that point. At that point, the gravitational force is considered to work vertically downward, with the same force as the weight of the object. On ships, the center of gravity can move due to the added mass, the mass removed, and the mass transferred [4].

The center of gravity of the ship will move in the direction of the center of gravity of the added mass, away from the direction of the center of gravity of the removed mass, and will move parallel with the displacement of the center of gravity of the displaced mass. Displacement from the center of gravity for each case is given by the following formulation [4].

$$
G G_{1}=\frac{w \times d}{w}
$$


Where

$\mathrm{GG}_{1} \quad$ : Shift of the center of gravity of the body

d : Distance of weight shifted

w : Mass of the weight shifted

W : Ship's displacement.

\section{B. Shaft Inclination}

The propeller shaft installation is influenced by the location of the output flange from the main engine and propeller. The location of the main engine is usually determined at the preliminary design stage. The location of the propeller is determined based on the diameter of the propeller and the clearance between the propeller and the hull of the ship. The location of the propeller is usually between the propeller tip and the baseline. The size of the propeller is also attempted in this range and is still underwater when fully loaded. But in practice, the propeller diameter can be greater than that range, especially for fast ships with small drafts and little or no ballast. For these conditions, the propeller is usually positioned below the baseline so that the propeller does not come out of the water when it is empty and the propeller clearance is met [2].

To accommodate the placement of the main engine and propeller, it is usually necessary to rake the shaft centerline. The shaft is generally raked downward going aft as this permits the main engines to be located higher in the ship. A large rake will have an effect in the form of a reduction in propulsive efficiency [2].

\section{Ship Resistance}

The total resistance of a ship is divided into the following components [5].

$$
R_{T}=R_{F}(1+K)+R_{A P P}+R_{W}+R_{B}+R_{T R}+R_{A}
$$

\footnotetext{
Where

$\mathrm{R}_{\mathrm{F}} \quad$ : Frictional resistance according to the ITTC 1957 formula.

$1+\mathrm{k} \quad$ : Form factor of the hull.

$\mathrm{R}_{\mathrm{APP}} \quad$ : Appendage resistance.

$\mathrm{R}_{\mathrm{W}} \quad$ : Wave resistance.

$\mathrm{R}_{\mathrm{B}}$ : Additional pressure resistance of bulbous bow near the water surface.

$\mathrm{R}_{\mathrm{TR}}$ : Additional pressure resistance due to transom immersion.

$\mathrm{R}_{\mathrm{A}} \quad$ : Model-ship correlation resistance.
}

Ship resistance according to ITTC standards, explained by the following formula

$R_{T}=\frac{1}{2} \rho V^{2} S C_{T}$

In this equation the density of water $(\rho)$ and velocity $(\mathrm{V})$ is constant. So the change in resistance is a function of the wet surface area $(\mathrm{S})$ and the total resistance coefficient of the ship $\left(\mathrm{C}_{\mathrm{T}}\right)$. To make a profit one or both must be reduced [6].

\section{The efficiency of Ship Propulsion Systems}

Not all power from the main engine reaches the propeller and is converted into thrust by the propeller. There are losses that occur during the process of transmitting power from the main engine to the propeller. Losses from the power are often expressed in terms of efficiency.

1. Hull efficiency

The ratio between effective power $\mathrm{P}_{\mathrm{E}}$ and thrust power $\mathrm{P}_{\mathrm{T}}$

$$
\begin{aligned}
& \eta h=\frac{1-t}{1-w} \\
& \text { Where } \\
& t=1-\frac{R_{T}}{T_{V a}} \\
& w=1-\frac{V a}{V s}
\end{aligned}
$$

2. Propeller efficiency

The ratio between thrust power $\mathrm{P}_{\mathrm{T}}$ and delivered power $\mathrm{P}_{\mathrm{D}}$

Propeller efficiency (open water test)

$$
\begin{aligned}
& \eta_{o}=\frac{T \times V a}{2 \times \pi \times n \times Q_{n}} \\
& \text { Propeller efficiency (behind the ship) } \\
& \eta_{b}=\frac{T \times V a}{2 \times \pi \times n \times Q_{h}}
\end{aligned}
$$

3. Relative rotative efficiency

The ratio between open water efficiency and efficiency behind the hull

$$
\eta_{r r}=\frac{\eta_{b}}{\eta_{o}}
$$

4. Propulsive efficiency

5. The ratio between effective power $P_{E}$ and delivered power $\mathrm{P}_{\mathrm{D}}$

$$
\begin{aligned}
& P C=\eta_{h} \times \eta_{o} \times \eta_{r r} \\
& P C=\eta_{h} \times \eta_{b}
\end{aligned}
$$

\section{E. Actuator Disk Propeller Methode (Momentum Propeller Theory)}

This theory assumes that the propeller is a disk with a stable motion that is able to provide a sudden increase in pressure on the fluid that passes through it. This theory ignores the effects of propeller rotation and whirlpools that occur at the tip of the propeller blade and frictional loss. Propeller provides uniform acceleration for all fluids that pass through it so that the thrust generated is evenly distributed to the disk. Fluid flow through the propeller is assumed to be without friction and there is an unlimited inflow of water to the propeller [7].

This method can be useful for calculating maximum efficiency and propeller speed estimates. However, the momentum theory does not provide information about the differential thrust of the propeller and torque on the blade, and the strength and bending moment of the propeller. Thus it was considered too simple for the propeller design analysis. So the momentum theory is considered far from the desired level of accuracy for the simulation model [8]. 


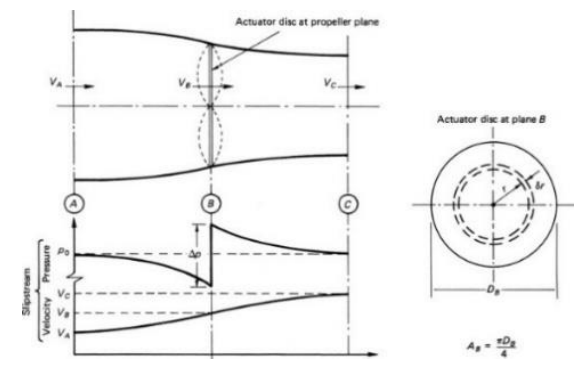

Figure. 1. Actuator Disk Propeller Theory

Figure 1 illustrates the change in flow in the annular tube as it passes through the actuator disk and there is an increase in pressure due to the onset of fluid flowing through the disk. Consideration of flow along the annular radius $r$ and thickness $\delta r$ on the propeller disk. Thrust and torque can be obtained from the change in momentum that occurs in the fluid flow downstream of the annular tube.

CFD-ADM is a commonly used analytical method that provides a solution from the Navier-Stokes or Euler classification in a domain consisting of a propeller which is represented through the body style distribution used on the disk area. From a distribution point of view, this distribution is obtained by questioning, such as discussing iteratively and interactively with the surface lifting method, blade elements [9].

\section{F. Computational Fluid Dynamic (CFD)}

CFD (Computational Fluid Dynamics) is a branch of fluid mechanics that solves and analyzes fluid flow problems using numerical methods and algorithms. CFD is used to accurately predict fluid flow, heat transfer, and chemical reactions in complex systems that include one or more of the phenomena described above. There are three key components of computational fluid dynamics:

- Pre-processor

The data input stage of Computational Fluid Dynamics (CFD), which involves the determination of domains and boundary conditions, is called the pre-processor. At this stage, the analyzed objects are divided into a certain number of grids, which is called meshing. [10].

TABLE 1.

PRINCIPAL DIMENSION OF SHIP

\begin{tabular}{lccc}
\hline \multicolumn{1}{c}{ Particular } & Symbol & Measure & Unit \\
\hline Length on waterline & Lwl & 21.980 & $\mathrm{~m}$ \\
Breadth moulded on WL & $\mathrm{B}$ & 5.200 & $\mathrm{~m}$ \\
Depth moulded & $\mathrm{D}$ & 2.300 & $\mathrm{~m}$ \\
Draught moulded on FP & $\mathrm{T}_{\mathrm{F}}$ & 1.600 & $\mathrm{~m}$ \\
Draught moulded on AP & $\mathrm{T}_{\mathrm{A}}$ & 1.600 & $\mathrm{~m}$ \\
Displacement volume moulded & $\Delta$ & 101.756 & $\mathrm{~m}^{3}$ \\
The mass density of seawater & & 1.025 & ton $/ \mathrm{m}^{3}$ \\
Wetted surface area bare hull & $\mathrm{S}$ & 128.235 & $\mathrm{~m}^{2}$ \\
LCB position from AP & & 9.266 & $\mathrm{~m}$ \\
Block coefficient & $\mathrm{C}_{\mathrm{B}}$ & 0.455 & \\
Midship section coefficient & $\mathrm{C}_{\mathrm{M}}$ & 0.854 & \\
Prismatic coefficient & $\mathrm{C}_{\mathrm{P}}$ & 0.621 & \\
Length-Breadth ratio & $\mathrm{L} / \mathrm{B}$ & 4.227 & $\mathrm{knot}$ \\
Breadth-Draught ratio & $\mathrm{B} / \mathrm{T}$ & 3.250 & \\
Service Speed & $\mathrm{Vs}$ & 9 & \\
\hline
\end{tabular}

TABLE 2

PROPELLER SPESIFICATION

\begin{tabular}{ll}
\hline \multicolumn{1}{c}{ Particular } & \multicolumn{1}{c}{ Specification } \\
\hline Propeller type & B-series \\
Number of blades & 4 \\
Diameter & $1 \mathrm{~m}$ \\
Pitch at diameter rasio (P/D) & 0,603 \\
Expanded area rasio (AE/A0) & 0,712 \\
Rotation & Clockwise \\
\hline
\end{tabular}




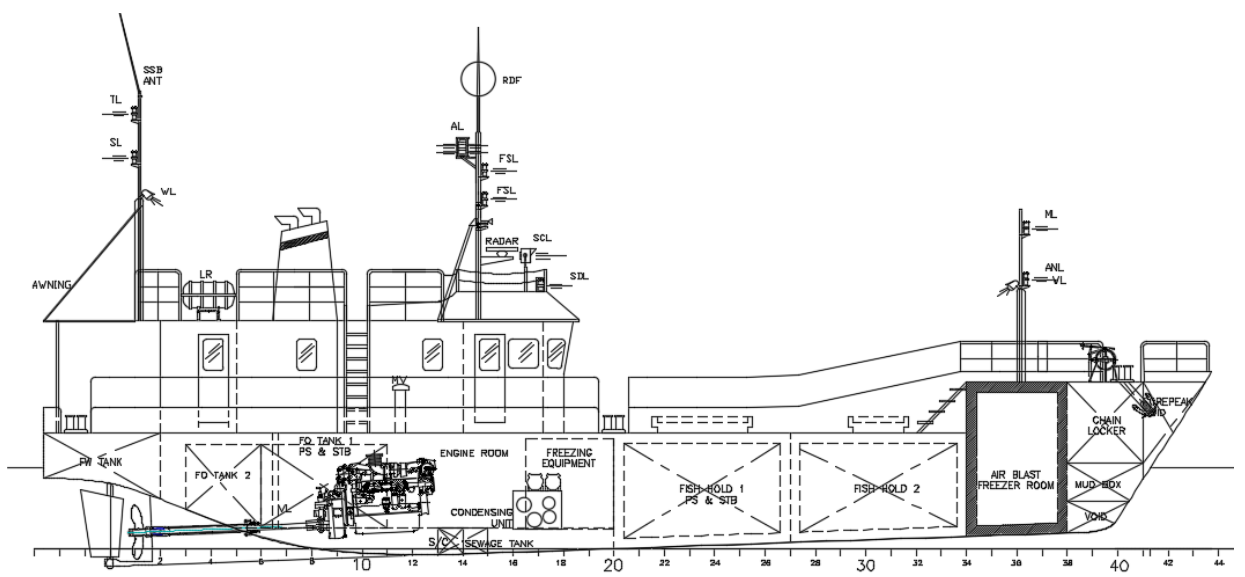

Figure. 2. Side view GA fishing vessel 60 GT.

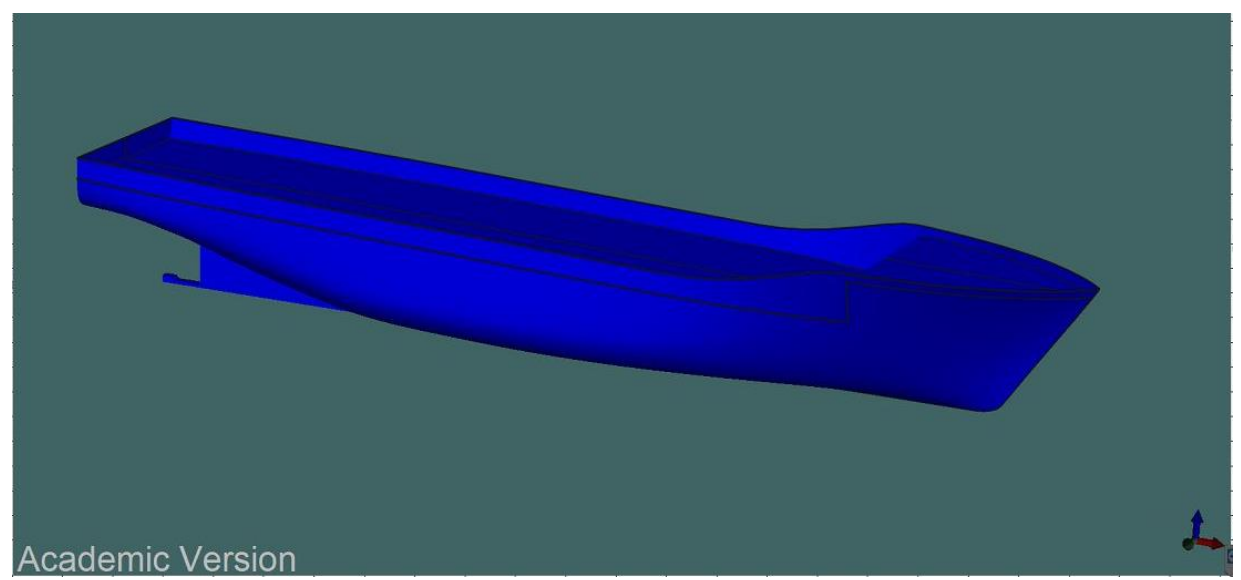

Figure. 3. Modeling results of fishing vessel $60 \mathrm{gt}$ using maxsurf modeller.

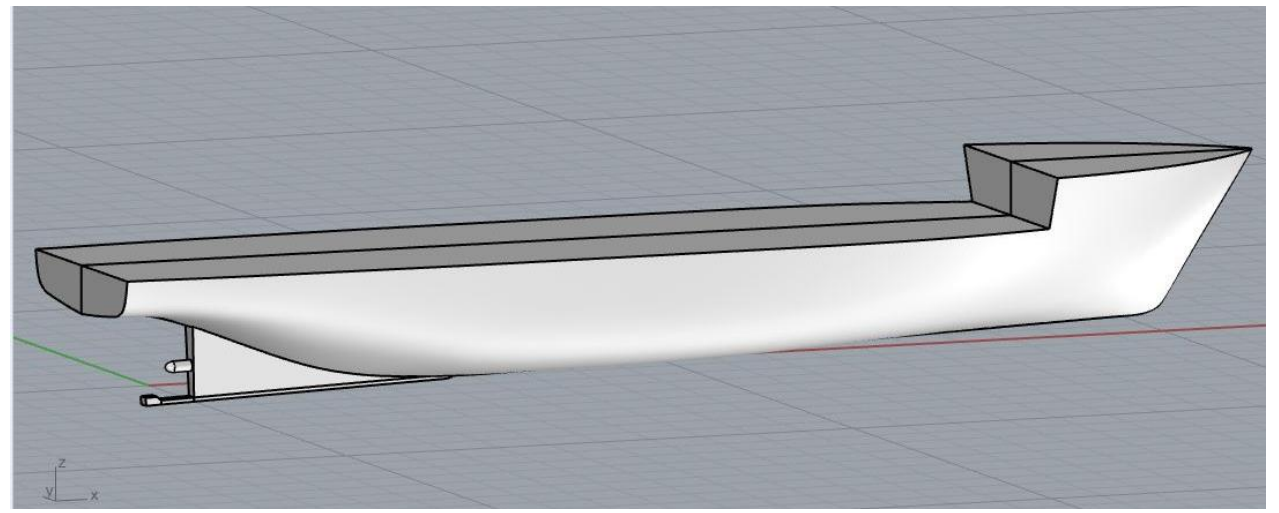

Figure. 4 Modeling results of fishing vessel $60 \mathrm{gt}$ in solid form using rhinoceros.

\section{- Processor}

The processor stage follows, where the process of iteratively measuring the data that has been entered using the relevant equation is carried out until the results obtained can reach the smallest error value is completed [10].

- Post-processor

The final stage is the post-processor stage, which displays the effects of the processor stage's calculations in images, graphics, and animation [10].

NUMECA is a trademark of an international company providing CFD processing software, NUMECA International. NUMECA has products for design and meshing processors and solvers for CFD processing software. Some of the software will be used in this thesis.

\section{METHOD}

\section{A. Ship Data}

This research uses a fishing vessel ship 60 GT with principal particulars as shown in table 1 and table 2 .

\section{B. Ship Modelling}

From the vessel data obtained, it can be made a ship model will be used in the simulation process with the Numeca Fine Marine software. Ship modeling is done by Maxurf Modeller software based on the ship lines plan that has been obtained. Then the model that has been made is exported into IGES (.igs) format to convert the ship model to a solid form. The ship model which consists of a collection of surfaces is converted into solid objects. Then modeling continued with Rhinoceros software. Models in the IGES (.igs) format are imported 
into Rhinoceros and then used to change the model in solid form to Parasolid (.x_t). The model in the form of Parasolid will be used for the simulation process with Numeca Fine Marine software. In addition to changing from a solid to a Parasolid form, Rhinoceros software is also used to adjust variations in the angle of the propeller shaft.

\section{Variation Setting}

In this research, the simulation was carried out on several variations of the propeller shaft inclination angle. There are 2 variations of the main engine placement and 4 variations of the propeller shaft inclination angle that will be analyzed in this research. The variation of the propeller shaft inclination is $1^{0}, 2^{\circ}, 3^{\circ} 4^{0}$. While the main engine position is at a distance of $4 \mathrm{~m}-6.5 \mathrm{~m}$ and $5.5 \mathrm{~m}-8 \mathrm{~m}$ from the AP. The configuration of the propeller shaft inclination angle and main engine placement are shown in table 3 .

TABLE 3.

\begin{tabular}{cccc}
\multicolumn{3}{c}{ PROPELLR SHAFT INCLINATION ANGLE AND MAIN ENGINE PLACEMENT VARIATION } \\
\hline No. & Configuration & Shaft Inclination Angle $\mathbf{(}^{(\mathbf{)}}$ & Main Engine Position (m) \\
\hline 1 & 1 & 1 & $4-6.5$ \\
2 & 2 & 2 & $4-6.5$ \\
3 & 3 & 3 & $4-6.5$ \\
4 & 4 & 4 & $4-6.5$ \\
5 & 5 & 1 & $5.5-8$ \\
6 & 6 & 2 & $5.5-8$ \\
7 & 7 & 3 & $5.5-8$ \\
8 & 8 & 4 & $5.5-8$ \\
\hline
\end{tabular}

\section{Simulation Process Using CFD software}

Simulation using Numeca Fine Marine starts with creating the domain. In NUMECA Hexpress, to start the first set which is to determine the size of the domain. Domain size has a standard boundary based on the standards prescribed so that the analysis results can correspond to the actual state of the environment. Stages of meshing on Numeca Fine Marine can be done automatically using $\mathrm{C}$-Wizard. The $\mathrm{C}$-wizard will make it easy to set up a domain, where the domain that is commonly used to test the resistance of using C-Wizard will automatically form a domain box based on ITTC standards.
The next step after domain creation complete is meshing. At this stage, the model is transformed from geometry into elements with smaller and specific nodes. Nets or meshing divides domains into smaller subdomains. A domain can mean the space limit for fluid analysis to be computerized. In the process of testing the model, each of these elements will be calculated by the Numeca Fine Marine software.

From the results of all the meshing stages, we will get the number of cells that will later be used in the calculation of the running or solver stage, the greater the number of cells produced will be longer the running time. From the meshing results, the number of cells is shown in table 4.

TABLE 4.

NUMBER OF CELLS IN EACH CONFIGURATION

\begin{tabular}{cccc}
\hline No. & Configuration & Number of cells & Number of verticals \\
\hline 1 & 1 & 1812370 & 1896370 \\
2 & 2 & 1956196 & 2053327 \\
3 & 3 & 1778192 & 1862591 \\
4 & 4 & 1797758 & 1887983 \\
5 & 5 & 1812370 & 1896370 \\
6 & 6 & 1956196 & 2053327 \\
7 & 7 & 1778192 & 1862591 \\
8 & 8 & 1797758 & 1887983
\end{tabular}

The next step is to configure flow simulation (flow need to be defined as shown in table 5. After all the setting) including the configuration of propeller actuator disk parameters. The following are the parameters that parameters have been determined, the simulation step (solver) can be run.

TABLE 5.

FLOW SETTING PARAMETER ON CONFIGURATION 1 (PART 1)

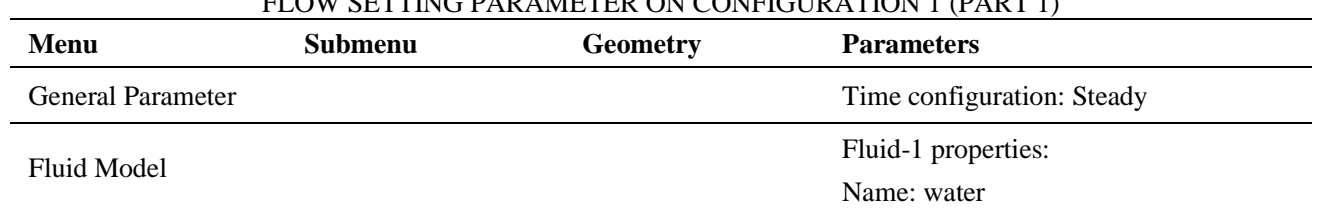


International Journal of Marine Engineering Innovation and Research, Vol. 6(1), Mar. 2021. 53-64 (pISSN: 2541-5972, eISSN: 2548-1479)

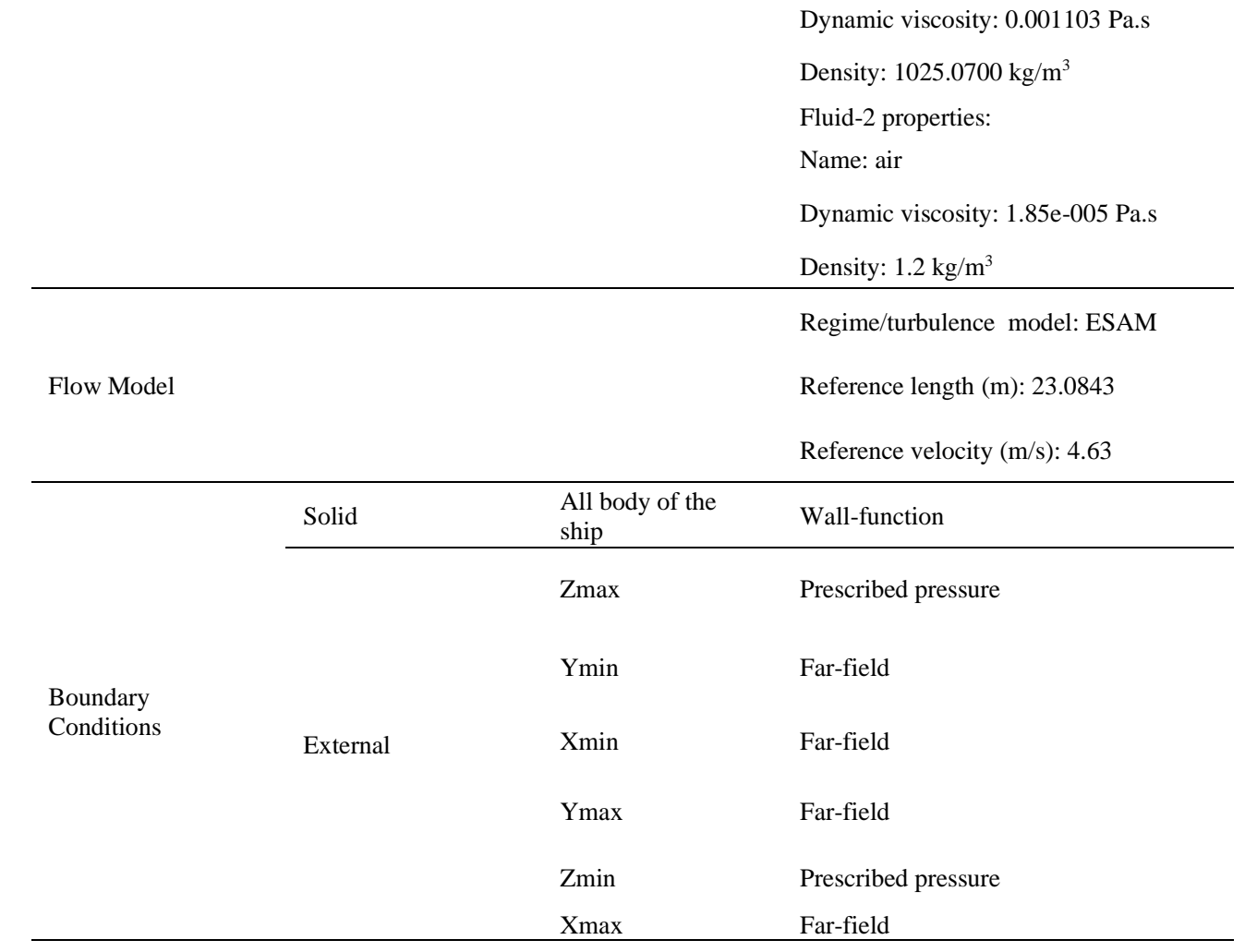

TABLE 5.

FLOW SETTING PARAMETER ON CONFIGURATION 1

(PART 2)

\begin{tabular}{|c|c|c|c|}
\hline Menu & Submenu & Geometry & Parameters \\
\hline Body definition & & & Vessel \\
\hline \multirow{9}{*}{ Body Motion } & \multirow{6}{*}{ Motion Definition } & & Tx0 (Surge): Imposed \\
\hline & & & Ty0 (Sway): Fixed \\
\hline & & & Tz0 (Heave): Solved \\
\hline & & & Rx2 (Roll): Fixed \\
\hline & & & Ry1 (Pitch): Solved \\
\hline & & & Rz0 (Yaw): Fixed \\
\hline & \multirow{3}{*}{ Dynamic Parameters } & & Geometry: the entire body \\
\hline & & & $\begin{array}{l}\text { Center of gravity: } \\
(9.2342,0,1.5743)\end{array}$ \\
\hline & & & Mass and inertia: $104299.9 \mathrm{~kg}$ \\
\hline \multirow{6}{*}{$\begin{array}{l}\text { Actuator Disk } \\
\text { Propeller }\end{array}$} & & & $\begin{array}{l}\text { Body force update: OPEN WATER } \\
\text { DATA }\end{array}$ \\
\hline & & & Inner radius: 0.1 \\
\hline & & & Outer radius: 0.5 \\
\hline & & & Thickness: 0.2 \\
\hline & & & $\begin{array}{l}\text { Center coordinates: } \\
(0.5702,0,0.3276)\end{array}$ \\
\hline & & & $\begin{array}{l}\text { Shaft direction } \\
(-1,0,-0.034921)\end{array}$ \\
\hline \multirow{5}{*}{ Control Variables } & \multirow{5}{*}{ General } & & $\begin{array}{l}\text { Maximum number of non-linear } \\
\text { iterations: } 5\end{array}$ \\
\hline & & & Convergence criteria: 2 orders \\
\hline & & & Save solution every: 100 \\
\hline & & & Number of time steps: 1000 \\
\hline & & & Time step value: 0.1 \\
\hline
\end{tabular}




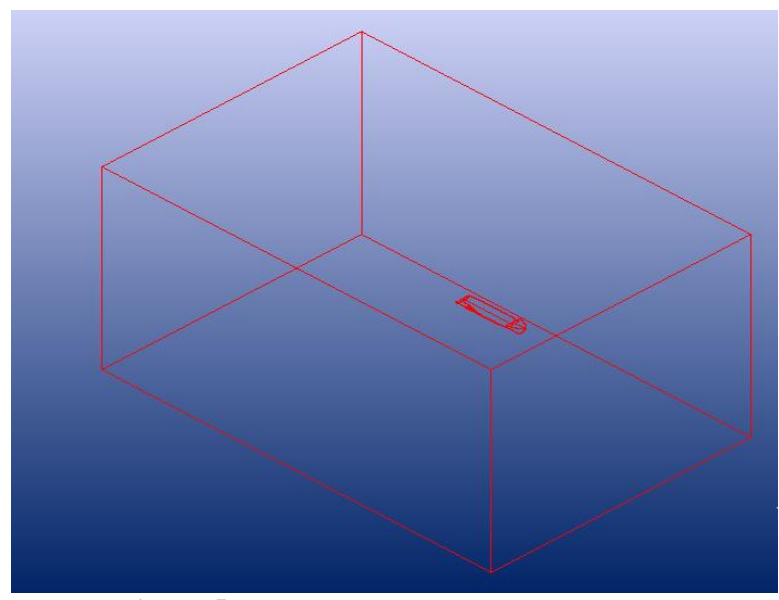

Figure. 5. Domain Creation Results in C-Wizard

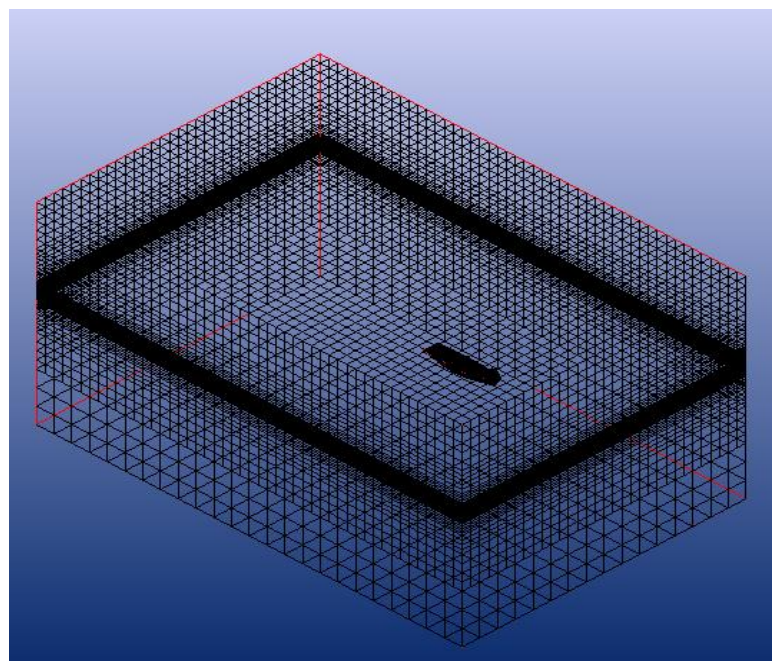

Figure. 6. Meshing Result

\section{RESULTS AND DISCUSSION}

The result of the test shown in table 6 and table 7 .

A. Model Simulation Result

TABLE 6.

MODEL SIMULATION RESULT FOR RESISTANCE, THRUST, TORQUE, AND PROPELLER ROTATION

\begin{tabular}{cccccccccc}
\hline No. & Configuration & $\begin{array}{c}\text { Propeller Shaft } \\
\text { Inclination } \\
\text { Angle }\left(\mathbf{(}^{\mathbf{0}}\right)\end{array}$ & $\begin{array}{c}\text { Main Engine } \\
\text { Position } \\
(\mathbf{m} \text { from AP) }\end{array}$ & $\mathbf{R t}(\mathbf{N})$ & $\mathbf{T}(\mathbf{N})$ & $\mathbf{Q}(\mathbf{N})$ & $\begin{array}{c}\mathbf{N} \\
(\mathbf{r p s})\end{array}$ & $\mathbf{W S A}\left(\mathbf{m}^{2}\right)$ & $\mathbf{R y}\left(\mathbf{(}^{\mathbf{0}}\right)$ \\
\hline 1 & 1 & 1 & $4-6.5$ & 10787.37 & 17805.69 & 2012.40 & 10.53 & 136.5045 & 0.1909 \\
2 & 2 & 2 & $4-6.5$ & 10489.00 & 17216.72 & 1947.71 & 10.42 & 136.5204 & 0.1930 \\
3 & 3 & 3 & $4-6.5$ & 10004.79 & 16940.36 & 1914.63 & 10.27 & 136.5663 & 0.1855 \\
4 & 4 & 4 & $4-6.5$ & 9648.97 & 16520.66 & 1867.46 & 10.15 & 136.8721 & 0.1915 \\
5 & 5 & 1 & $5.5-8$ & 11146.82 & 19189.54 & 2158.75 & 10.71 & 136.0228 & 0.1837 \\
6 & 6 & 2 & $5.5-8$ & 11807.43 & 19569.18 & 2205.88 & 10.89 & 135.9921 & 0.1858 \\
7 & 7 & 3 & $5.5-8$ & 11418.73 & 19043.18 & 2147.42 & 10.76 & 136.0688 & 0.1844 \\
8 & 8 & 4 & $5.5-8$ & 11506.48 & 18901.44 & 2133.90 & 10.78 & 136.4043 & 0.1893 \\
\hline
\end{tabular}

TABLE 7.

MODEL SIMULATION RESULT FOR KT, KQ, J, PROPELLER EFFICIENCY

\begin{tabular}{|c|c|c|c|c|c|c|c|}
\hline No. & Configuration & $\begin{array}{c}\text { Propeller Shaft } \\
\text { Inclination Angle }\left(^{0}\right)\end{array}$ & $\begin{array}{l}\text { Main Engine } \\
\text { Position } \\
\text { (m from AP) }\end{array}$ & KT & KQ & $\mathbf{J}$ & n Prop. \\
\hline 1 & 1 & 1 & $4-6.5$ & 0.1572 & 0.0177 & 0.2820 & 0.3981 \\
\hline 2 & 2 & 2 & $4-6.5$ & 0.1552 & 0.0175 & 0.2871 & 0.4047 \\
\hline
\end{tabular}




\begin{tabular}{llllllll}
\hline 3 & 3 & 3 & $4-6.5$ & 0.1572 & 0.0177 & 0.2821 & 0.3983 \\
4 & 4 & 4 & $4-6.5$ & 0.1569 & 0.0177 & 0.2827 & 0.3991 \\
5 & 5 & 1 & $5.5-8$ & 0.1636 & 0.0184 & 0.2659 & 0.3771 \\
6 & 6 & 2 & $5.5-8$ & 0.1613 & 0.0181 & 0.2717 & 0.3847 \\
7 & 7 & 3 & $5.5-8$ & 0.1608 & 0.0181 & 0.2730 & 0.3864 \\
8 & 8 & 4 & $5.5-8$ & 0.1591 & 0.0179 & 0.2771 & 0.3918 \\
\hline
\end{tabular}

B. Comparison of Maxsurf Calculation Results, Simulation, and Resistance Test.

The results of CFD simulations then performed a comparison or validation of data with the calculation of Maxsurf Resistance using the Oortmerssen and Holtrop

methods, as well as the results of the resistance test. Comparisons were made to the value of ship resistance at a speed of 9 knots, the main engine position $4 \mathrm{~m}-6.5 \mathrm{~m}$ from the AP, and the angle of the propeller shaft $2^{\circ}$ which is the initial condition of the ship in this study. The comparison is shown in table 8 .

TABLE 8.

COMPARISON OF RESISTANCE

\begin{tabular}{llcc}
\hline \multicolumn{2}{c}{ Methode } & $\begin{array}{c}\text { Total Resistance } \\
(\mathbf{k N})\end{array}$ & Error \\
\hline \multirow{2}{*}{ Maxsurf } & Oortmerssen & 10.80 & $2.96 \%$ \\
& Holtrop & 9.90 & $5.62 \%$ \\
Pengujian & 10.20 & $2.76 \%$ \\
Numeca & 10.49 & - \\
\hline
\end{tabular}

From table 8 . it can be seen that the total resistance value from the Maxsurf Resistance calculation, resistance test, and simulation has a difference that is not too large with an error of less than $10 \%$. So it can be said that the simulation data from Numeca Fine Marine is valid.

\section{Resistance Analysis}

Based on the analysis results from table 6 and the graph in Figure 7, the smallest total resistance value is in configuration 4 with the propeller shaft inclination angle $4^{0}$ and the main engine position is at $4 \mathrm{~m}-6.5 \mathrm{~m}$ from the AP. The total resistance value in this configuration is 9648.97 N. The total resistance value tends to be of less value at the angle of the propeller shaft which is bigger and more valuable when the main engine position is at $5.5 \mathrm{~m}-8 \mathrm{~m}$ from the AP. Ship resistance is a function of the density of seawater, speed of the ship, the wet surface area of the ship, and the coefficient of resistance of the ship. The density of seawater and the speed of the ship are constant so that the parameters that affect the change in the magnitude of the ship's resistance are the wet surface area and the coefficient of ship resistance [6]. The thrust produced by the propeller will be parallel to the propeller shaft so that on a ship with a propeller shaft that has a rake in the vertical direction, the thrust will cause a trim on the ship. In this research, the ship experienced trim by the stern as in table 6 . When the ship experiences a wide trim by stern the wet surface will increase due to the shape of the hull which tends to be fatter on the stern. However, the value of the ship's resistance from the simulation results when the ship experiences trim by stern becomes smaller. This shows that when the ship experiences trim by stern, the value of the ship resistance coefficient becomes smaller. The inclination of the propeller shaft angle causes greater stern trim so that the ship's resistance will be smaller. The main engine shift will affect the center of gravity of the ship. The main engine shift from $4 \mathrm{~m}-6.5 \mathrm{~m}$ from AP to $5.5 \mathrm{~m}-8 \mathrm{~m}$ from AP causes the center of gravity to shift towards FP. Shifting the center of gravity will reduce the stern trim of the ship so that the ship's resistance will increase.

Figures 8 and figure 9 show free surface waves generated by ship motion. From this figure, it can be seen the difference in waves generated by the causes differences in the value of ship resistance obtained from the simulation. The greater the waves generated by the ship, the resistance value will also be greater.

\section{Thrust Analysis}

Based on the analysis results in table 6 and the graphs in figures 10 and figure 11 , the lowest thrust and torque parameters in configuration 4 with propeller shaft inclination angle $4^{\circ}$ and main engine position are at $4 \mathrm{~m}$ $6.5 \mathrm{~m}$ from AP. The value of the thrust in that configuration is $16520.66 \mathrm{~N}$ and the torque value is $1867.46 \mathrm{Nm}$. These parameters tend to decrease with increasing shaft inclination and tend to be higher in the main engine position at $5.5 \mathrm{~m}-8 \mathrm{~m}$ from the AP. In the simulation with Numeca Fine Marine, the final speed of the ship in each configuration is made equal to 9 knots. Smaller thrust and torque will make the power needed to make the ship go with the same speed is smaller.

The next parameter that needs to be analyzed is propulsion efficiency. The propulsion efficiency value can be found using the Open Water Diagram of the propeller and the $\mathbf{J}$ value in table 7 . The value of $\mathbf{J}$ is plotted on the Open Water Diagram and the intersection with the $\mathrm{KT}, \mathrm{KQ}$, and propulsion efficiency is shown in figure 12 . From these intersections obtained the value of $\mathrm{KT}$, KQ, and propulsion efficiency. Propulsion efficiency values can also be found using the formula $\eta_{O}=\frac{J \times K T}{2 \pi \times K Q}$. From the two methods, you will get the same propulsion efficiency value as in table 7 
International Journal of Marine Engineering Innovation and Research, Vol. 6(1), Mar. 2021. 53-64 (pISSN: 2541-5972, eISSN: 2548-1479)

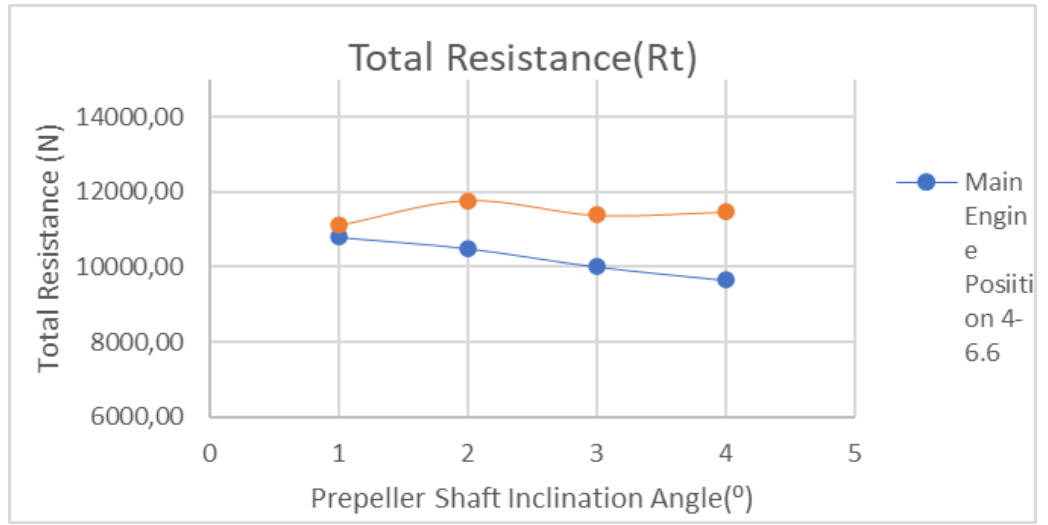

Figure. 7 Total resistance of each configuration.

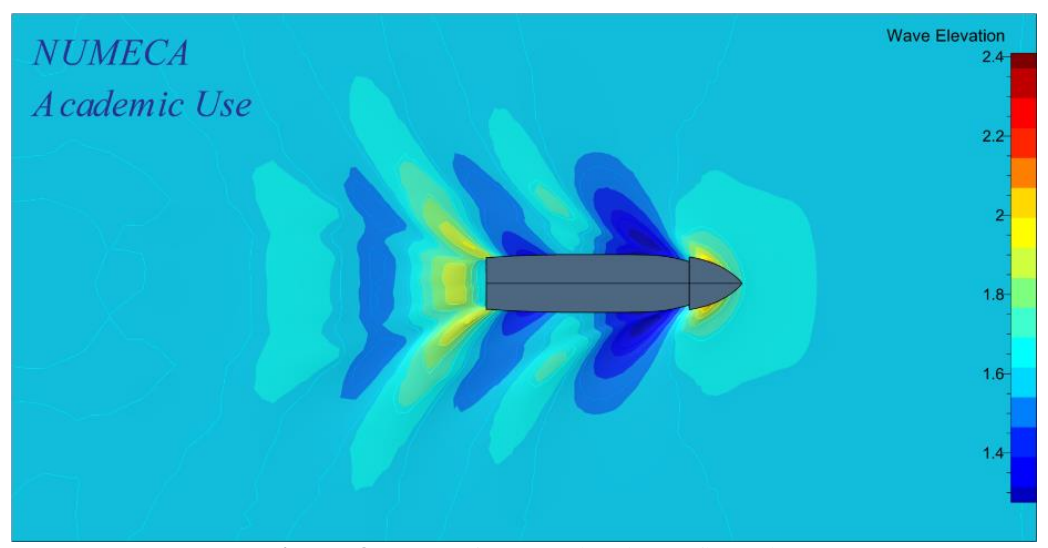

Figure. 8 Free surface top view in configuration 4.

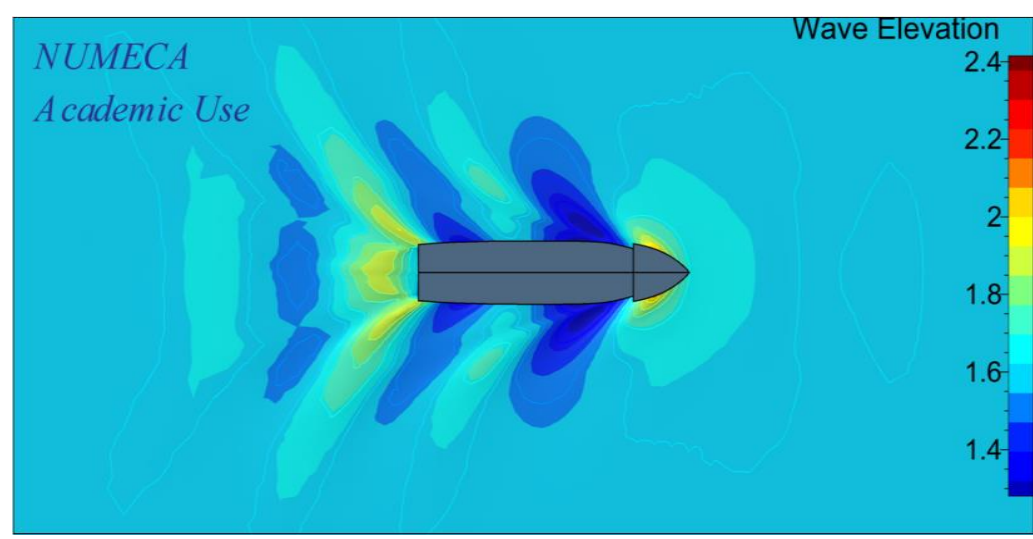

Figure. 9 Free surface top view in configuration 5.

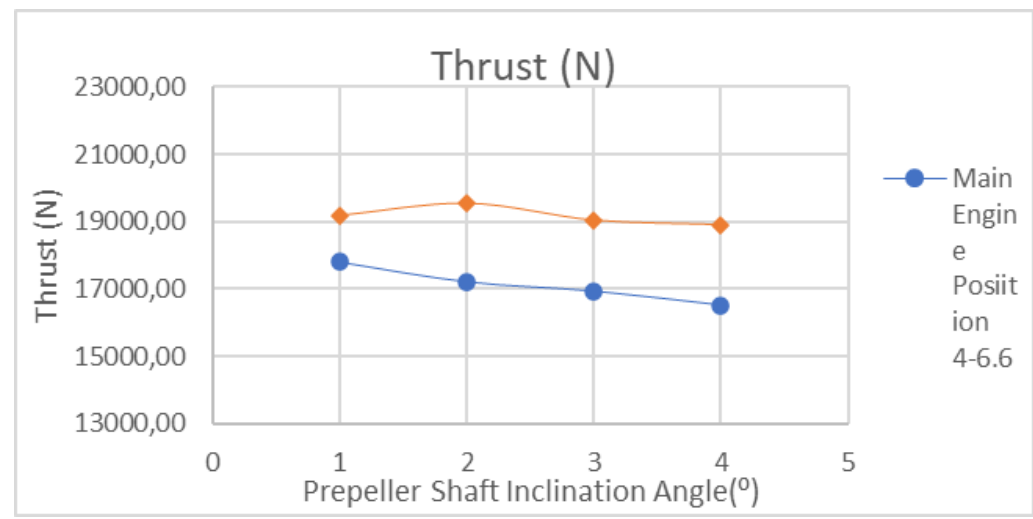

Figure. 10. The thrust of each configuration. 


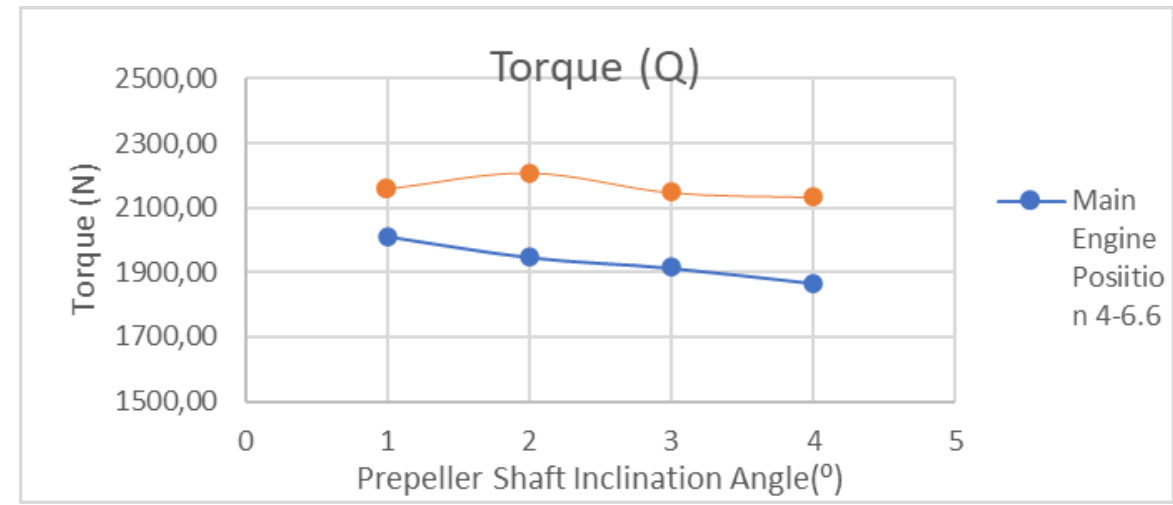

Figure. 11. The torque of each configuration.

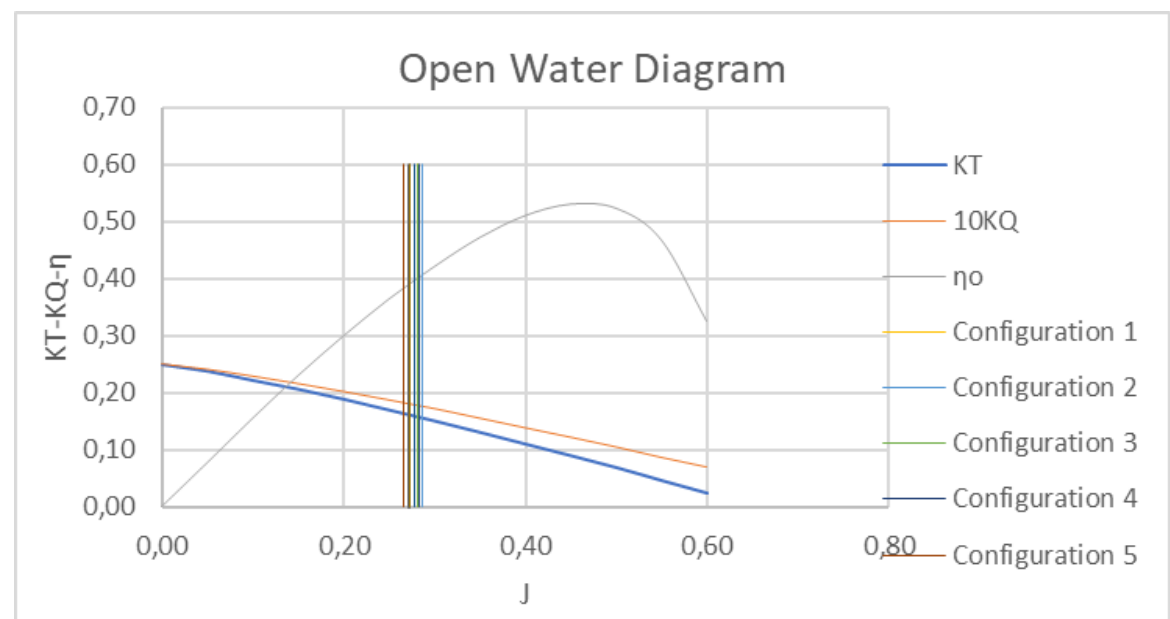

Figure. 12. Propeller efficiency analysis of each configuration.

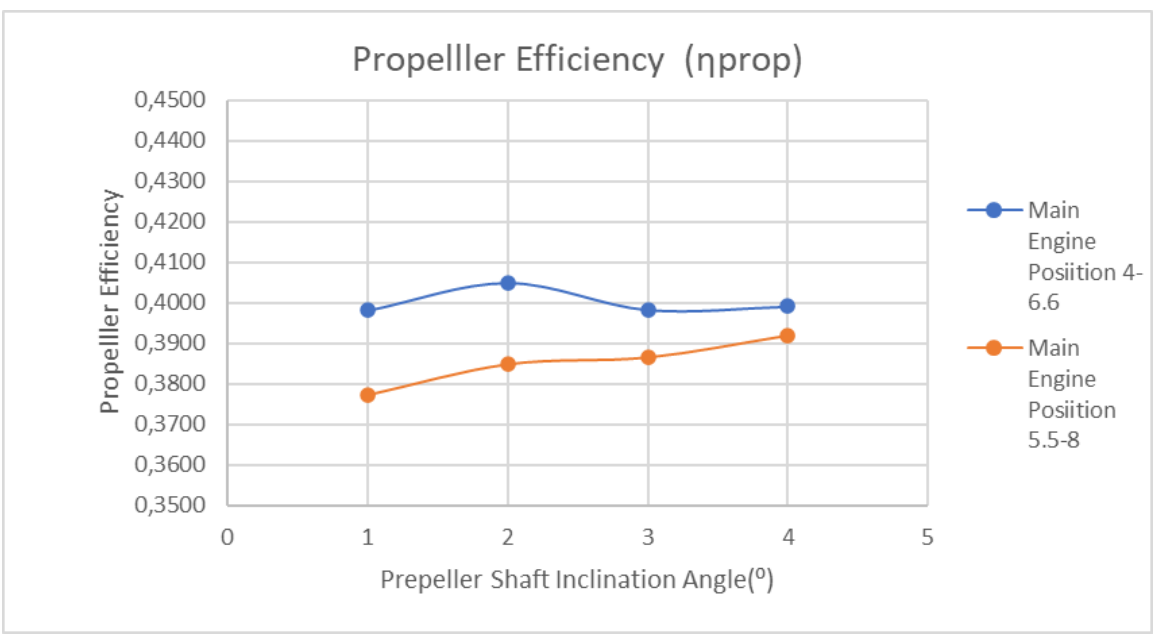

Figure. 13. Propeller efficiency of each configuration.

Based on the analysis results in table 7 and the graph in Figure 13, the highest value of propulsion efficiency is in Configuration 2 with the propeller shaft inclination angle $2^{0}$ and the main engine position is at $4 \mathrm{~m}-6.5 \mathrm{~m}$ from the AP. The efficiency of propulsion in the configuration is
0.4047. This happens because the placement of the propeller with the hull of the stern has suitability so that the impact on the speed of water flow through the high propeller as propeller work. For fluid flow through the propeller can be seen in Figures 14 to 17. 


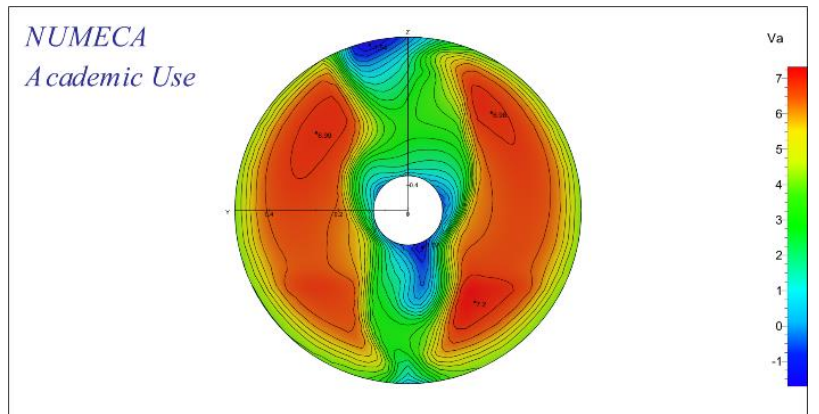

Figure. 14. Wake flow actuator disk propeller in configuration 2.

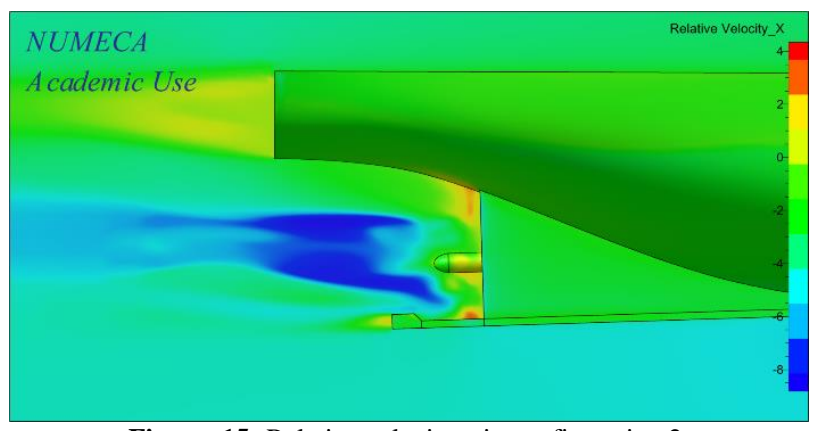

Figure. 15. Relative velocity $\mathrm{x}$ in configuration 2.

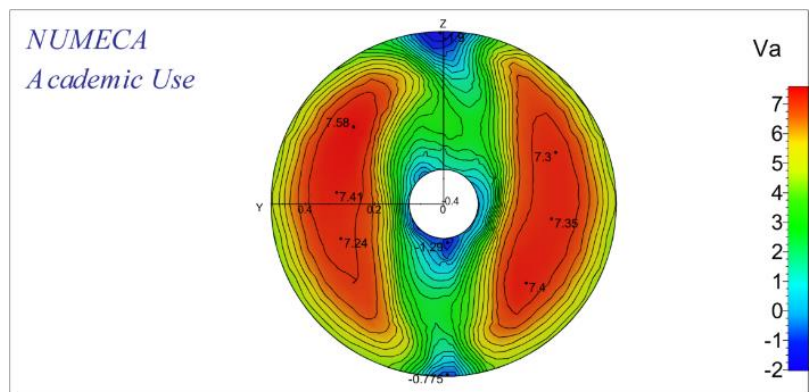

Figure. 16. Wake flow actuator disk propeller in configuration 5.

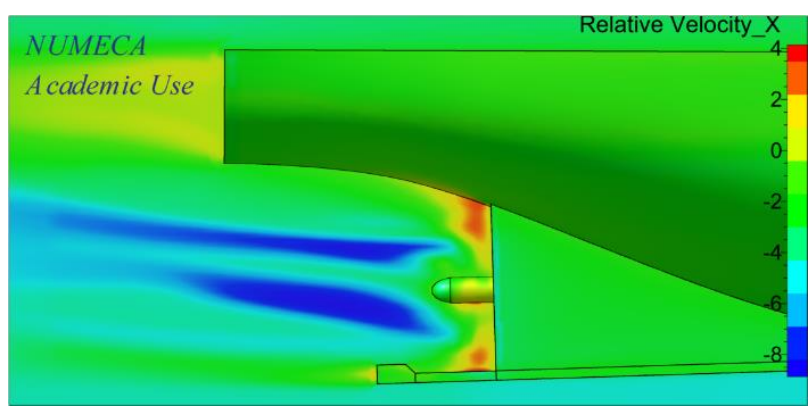

Figure. 17. Relative velocity $\mathrm{x}$ in configuration 5 .

From the CFView wake flow actuator disk propeller image and relative velocity in each configuration, it can be seen that in configuration 2 where the propulsion efficiency has the highest value of fluid flow it looks more homogeneous than the other configurations although the difference is not too significant. This shows that the interaction between propeller and hull in configuration 2 is better than in other configurations. Interaction between the propeller and the hull produces wake flow. The result of the velocity of water flowing to the propeller is advanced velocity. Advance velocity values can be searched using equation 7. Advance velocity values for each configuration are shown in table 9. 
TABLE 9.

MODEL SIMULATION RESULT FOR ADVANCED VELOCITY

\begin{tabular}{cccc}
\hline No. & Configuration & Propeller Shaft Inclination Angle $\left(^{\mathbf{0}}\right)$ & Va $(\mathbf{m} / \mathbf{s})$ \\
\hline 1 & 1 & $4-6.5$ & 2.98 \\
2 & 2 & $4-6.5$ & 3.00 \\
3 & 3 & $4-6.5$ & 2.90 \\
4 & 4 & $4-6.5$ & 2.88 \\
5 & 1 & $5.5-8$ & 2.85 \\
6 & 2 & $5.5-8$ & 2.96 \\
7 & 3 & $5.5-8$ & 2.94 \\
\hline
\end{tabular}

The value of advance velocity is directly proportional to the value of $\mathbf{J}$ according to the equation $\mathbf{J}=\mathrm{Va} / \mathrm{ND}$. In accordance with the Open Water Diagram in Figure 12 for a value of $\mathrm{J}$ less than 0.5 , the greater the value of $\mathrm{J}$, the efficiency of propulsion will be even greater. From table 9 it can be seen that the highest advance velocity value is in configuration 2 where the configuration also has the highest propulsion efficiency.

\section{CONCLUSION}

Based on the results of the simulation, the analysis and discussion that had been done in the previous chapter obtained several conclusions as follows:

1.The propeller shaft inclination angle influences the performance of the $60 \mathrm{GT}$ fishing vessels tested in this study, where the greater the propeller shaft inclination angle, the resistance value will be smaller, thus requiring smaller thrust to move the ship at the same speed.

2.The placement of the main engine has an influence on the performance of the 60 GT fishing vessels tested in this study, where when the main engine is shifted towards FP, the resistance value will be greater so that it requires greater thrust to move the boat at the same speed.

3.The most optimum configuration in this study is configuration 4 at propeller shaft tilt angle 4 main and main engine position $4 \mathrm{~m}-6.5 \mathrm{~m}$ from AP, wherein this configuration has the smallest value of resistance, thrust, and torque. In this configuration, the total resistance value of the ship $=9648.97 \mathrm{~N}$ and the thrust force $=16520.66$, torque $=1867.46, \mathrm{KT}=0.1569, \mathrm{KQ}$ $=0.0177, \mathrm{~J}=0.2827$ and propulsion efficiency $=$ 0.3991 .

\section{REFERENCES}

[1] H. K. Prasetya, E. S. Koenhardono dan I. R. Kususma, "Perencanaan Sistem Propulsi Hybrid Untuk Kapal Fast Patrol Boat 60 M," Jurnal Teknik ITS, vol. 5, no. 2, p. B412, 2016.

[2] R. L. Harrington, Marine Engineering, New Jersey: The Society Of Naval Architects and Marine Engineers, 1992.

[3] A. Santoso, "Materi Kuliah Sitem Transmisi Tenaga," Surabaya, 2016.

[4] D. R. Derrett dan C. B. Barrass, Ship Stability for Masters and Mates, Fifth Edition, Oxford: Butterworth-Heinemann, 1999.

[5] J. Holtrop dan G. G. J. Mennen, "An Approximate Power Prediction Method," International Shipbuilding Progress, ISP, vol. 29, pp. 166-170, 1982.
[6] M. A. Santoso, Studi Kasus Analisis Pengaruh Trim Terhadap Penghematan Bahan Bakar dan Stabilitas Kapal, Surabaya: Teknik Perkapalan, ITS, 2017.

[7] E. V. Lewis, Principles of Naval Architecture Second Revision Volume II, New Jersey: The Society of Naval Architecture and Marine Engineers, 1998.

[8] A. Sahid, Analisa Aliran Fluida Pada Buritan Lambung KM. Kelola Mina Makmur 150 GT Berdasar Propeller and Hull Maatching Dengan Menggunakan Actuator Disk Propeller, Surabaya: Tenik Sistem Perkapalan, ITS, 2019.

[9] R. Bontempo dan M. Manna, "Actuator disc methods for open propellers: assessments of numerical methods," Engineering Applications of Computational Fluid Mechanics, vol. 11, no. 1, pp. 42-53, 2017.

[10] E. Jadmiko, I. Syarif dan L. Arif, "Comparison of Stern Wedge and Stern Flap on Fast Monohull Vessel Resistance," International Journal of Marine Engineering Innovation and Research, vol. 3, no. 2, pp. 041-049, 2018.

[11] NUMECA, "Theory Guide FINETM/Marine 8.1," NUMECA International., 2019. 